\title{
The Effect of Audio Visual Graphics in Perwali Implementation No 15 of 2016 on the Effectiveness of the Service Grant Recipients (Bansos) in the City of Bogor
}

\author{
Heri Susanto $^{a, 1,}$ Abdul Muis Miraza ${ }^{b, 2}$ \\ 1,2 Program Studi Manajemen, Fakultas Ekonomi Universitas Nusa Bangsa, Bogor, Indonesia \\ Email: dataheri2020@gmail.com, abdul_muis56@yahoo.co.id \\ *Corresponding Author
}

ARTICLE INFO

Article history

Received 2020-03-31

Revised 2020-08-28

Accepted 2020-09-14

Keywords

Effectiveness

Educational Elements

Social

Economic

Culture

\begin{abstract}
Effective in the service is part of the duties of the State Civil Apparatus (ASN) relating to the relationship of output responsibility with the goals to be achieved. The greater the output produced from the target to be achieved, it can be said to be effective. One of the efforts to improve services by Staf Kesra dane Kemasyarakatan Setda Kota Bogor is by using the Audio Visual Graphic (AVG). The impact of improving services will provide motivation for other employees in the local government to do work more effectively and assist in the implementation of other local government programs. This research uses a quantitative approach emphasizing its analysis on numerical data (numbers) which are processed, while the type of research used is descriptive and exploratory research, that is the type of research used based on its function, then by statistical methods multiple linear regression methods note that partially Audio Visual Graphic (as variable X) which includes educational elements (X1), social (X2), economical (X3) and culture (X4), use of Audio Visual Graphic in the implementation of guardian No. 15 of 2016 only economic elements that affect the effectiveness of the service recipient of grants/social assistance at the district of Bogor, which is equal to 0.321 .
\end{abstract}

\section{INTRODUCTION}

The Bogor City Government, which is adjacent to the capital city of the State, Jakarta, is still working to increase the acceleration of development through various programs, one of which is the role of the Bogor City Government in providing grants / social assistance to individuals, community groups and others. The fundamental reason for granting grants / social assistance is aimed at supporting the achievement of the targets of programs and activities of the local government, especially the Bogor City Government, by taking into account the principles of justice, decency, rationality, and benefits for the community. The granting of grants / social assistance must really support the achievement of targets and performance of the government and not to support the image of regional government performance. (Lapananda 2013)

The position of grants and social assistance funds is one of the government's efforts to minimize or reduce the level of poverty in an area, so the financial management of grants and social assistance must be in accordance with UU no. 17 of 2003, PP. 58 of 2005, Permendagri No. 13 of 2006, as amended several times, most recently by Permendagri No. 21 of 2011 and Permendagri No. 32 of 2011 as amended several times, most recently by Permendagri No. 14 of 2016. (Sianturi 2017). The provision of grants or social social assistance must be based on the designation specifically stipulated in the proposal, not mandatory and not binding, temporary and not continuous every fiscal year, unless otherwise stipulated by laws and regulations and meet the requirements for receiving a grant. The two factors that influence the implementation of grants and social assistance are influenced by indicators of financial report presentation, indicators of financial report accessibility and indicators of regional financial accounting systems. (Harahap 2018).

To point out the tendency for the allocation of grants and social assistance to be used as a more pork barrel political strategy by targeting areas that are the voting base for incumbent candidates and certain influential religious groups. This study also confirms that the pork barrel concept can be 
developed from its initial concept to include policies initiated by the executive and can occur at the local level. the application of demonstration methods and VCD media in learning basic human needs practicum.

Grants/ Bansos are sourced from a special budget sourced from the APBD and this must be based on the Regional Head regulations regarding budgeting, implementation and administration, accountability and reporting as well as monitoring and evaluation of grants in this case in the City of Bogor. Regulations concerning the procedures for budgeting, implementation and administration, accountability and reporting as well as monitoring and evaluation of grants, namely Bogor Mayor Regulation/ Perwali Number 15 of 2016 concerning Guidelines for the Implementation of Grants / Social Assistance sourced from the Regional Revenue and Expenditure Budget (APBD). The most basic reason for the appointment of the title in writing, one of which is the constraints in the effectiveness of services carried out by the Public Welfare and Community Staff (KEMAS) of the Bogor City Secretariat on the implementation of Perwali No. 15 of 2016 concerning the implementation instructions for grants/ social assistance that originate from the Bogor City APBD. (Susanto, 2017)

Effective service is part of the duties of the State Civil Apparatus (ASN) relating to the relationship between the output of responsibility and the goals that must be achieved. The greater the output resulting from the target to be achieved, it can be said to be effective. Effectiveness is how well the work is done, the extent to which a person produces the expected output.

In human resource management, there are six elements $(6 \mathrm{M})$, namely men, money, methods, materials, machines and markets. This men (Human) element develops into a field of science called human resource management or abbreviated as HRM. HR can also be referred to as personnel. In the workforce personnel, workers, employees, human potential as the driving force of the organization in realizing its existence, or potential which is an asset and functions as non-material capital in a business organization, which can be transformed into a real potential physically and nonphysically in realizing organizational existence (Nawawi , 2012)

Effective is the root word, while the adjective of effective is effectiveness. According to Effendy (2003) defines effectiveness as: "Communication whose process reaches the planned goals in accordance with budgeted costs, set time and specified number of personnel" (Effendy, 2003: 14). The definition of effectiveness according to Hadayaningrat in the book Principles of Management Organization is "Effectiveness is a measurement in the sense of achieving predetermined goals or objectives" (Handayaningrat, 2003)

Audio-visual media is defined as media that has sound and image elements. This media has better capabilities than audio media, because it combines the two types of media, namely Audio and Visual Media. Understanding according to audio-visual based media according to (Arsyad, 2002) visual is a visual media that contains the use of additional sound to produce it.

On the implementation of Perwali No. 15 of 2016 in Audio Visual contains learning activities for grant recipients / social assistance.

The function of media in learning in the context of communication has a very broad function, namely as follows:

1. Educative function, providing educational value influence, educating students and society to think critically, providing meaningful experiences, and developing and broadening students' thinking horizons.

2. Social function, providing authentic information in various fields of life and the same concept to everyone so as to expand relationships, recognition, understanding of people, customs and ways of getting along.

3. Economic function, by using educational media the achievement of goals can be carried out efficiently, delivery of material can reduce the use of costs, energy and time as little as possible without reducing effectiveness in achieving goals.

4. Cultural functions, providing changes in the aspects of human life, can pass on and carry on cultural and artistic elements that exist in society (Arindawati, 2004re). 
According to Parasuraman in Lupiyoadi \& Hamdani (2011) that there are five dimensions in service, namely:

1. Tangible (tangiable), namely the ability of a company to show its existence to external parties. The appearance and ability of the company's physical facilities and infrastructure that can be relied on by the surrounding environment is clear evidence of the services provided by the service provider.

2. Reliability, namely the company's ability to provide services as promised accurately and reliably.

3. Responsiveness, which is a policy to help and provide fast (responsive) and accurate service to customers, with clear information delivery. Let consumers wait for negative perceptions of service quality.

4. Assurance and assurance, namely the knowledge, politeness and ability of company employees to foster customer trust in the company.

5. Empathy (empathy), namely giving sincere and individual attention orpersonalities given to customers by seeking to understand desiresconsumer.

So far the services provided by the Public Welfare Staff and Community of the Bogor City Secretariat (Sekretariat Daerah Kota Bogor) are manual. It means that they do not use tools or hardware that make it easier for the members of the community who receive the grants so that services are felt slow with long waiting queues. So that there were many complaints from the community who received the grants in dealing with the Public Welfare Staff and the Community of the Bogor City Secretariat. This has been going on for a long time, therefore, the staff of the People's Welfare and Society of the Bogor City Secretariat are trying to innovate by providing services that are more professional and in accordance with their respective duties. One of them is the use of Audio Visual Graphics, the use of Audio Visual Graphics aims to increase understanding for Grant recipients / Bansos through Audio (sound), Visual (images), and Audio Visual with educational, social, economic and cultural elements so that it is expected to be effective in increasing participation community in the implementation of regional development or functionally through support for government administration, namely in the implementation of Perwali No. 15 of 2016 regarding the implementation instructions for grants / social assistance that originate from the Bogor City Regional Budget (APBD).

Based on the background above, the following problems can be formulated:

1. Does the use of Audio Visual Graphics with educational elements affect the effectiveness of grantees / social assistance services in Bogor City?

2. Does the use of Audio Visual Graphic with social elements affect the effectiveness of grantees / social assistance services in Bogor City?

3. Does the use of Audio Visual Graphic with economic elements affect the effectiveness of grantees / social assistance services in Bogor City?

4. Does the use of Audio Visual Graphics with cultural elements affect the effectiveness of grantees / social assistance services in Bogor City?

5. Does the use of Audio Visual Graphics in the Implementation of Perwali No. 15/2016 affect the effectiveness of grantees / social assistance services in Bogor City?"

\section{Research Objectives}

The purpose of this study was to determine how much influence the use of Audio Visual Graphics (AVG) has on the effectiveness of grantees / social assistance services in implementing Perwali No. 15 of 2016 regarding the implementation instructions for grants / social assistance that originate from the Bogor City Regional Budget (APBD).

\section{RESEARCH METHODS}




\section{Type of Research}

In this study, the type of research used is descriptive and explorative research, that is, the type of research used is based on its function. Descriptive research is making descriptions, descriptions or paintings in a systematic, factual and accurate manner regarding the facts, traits and relationships between the phenomena being investigated, which are related to the use of Audio Visual Graphics on effectiveness in grantees / social assistance services in the Bogor City Region in conducting implementation of grant / social assistance regulations sourced from the APBD.

Research with a quantitative approach emphasizes its analysis on numerical data (numbers) processed by statistical methods. (Sanusi, 2011)

\section{Variable Operationalization}

In this case the writer defines variable $1(\mathrm{X})$ is the use of AVG which contains educational (X1), social (X2) and economic (X3) and cultural (X4) elements towards variable 2 (Y), namely the effectiveness of grantees / social assistance services in Bogor City area where we want to know the effect between the use of AVG on the effectiveness of the grantees / social assistance services.

\section{Research Framework}

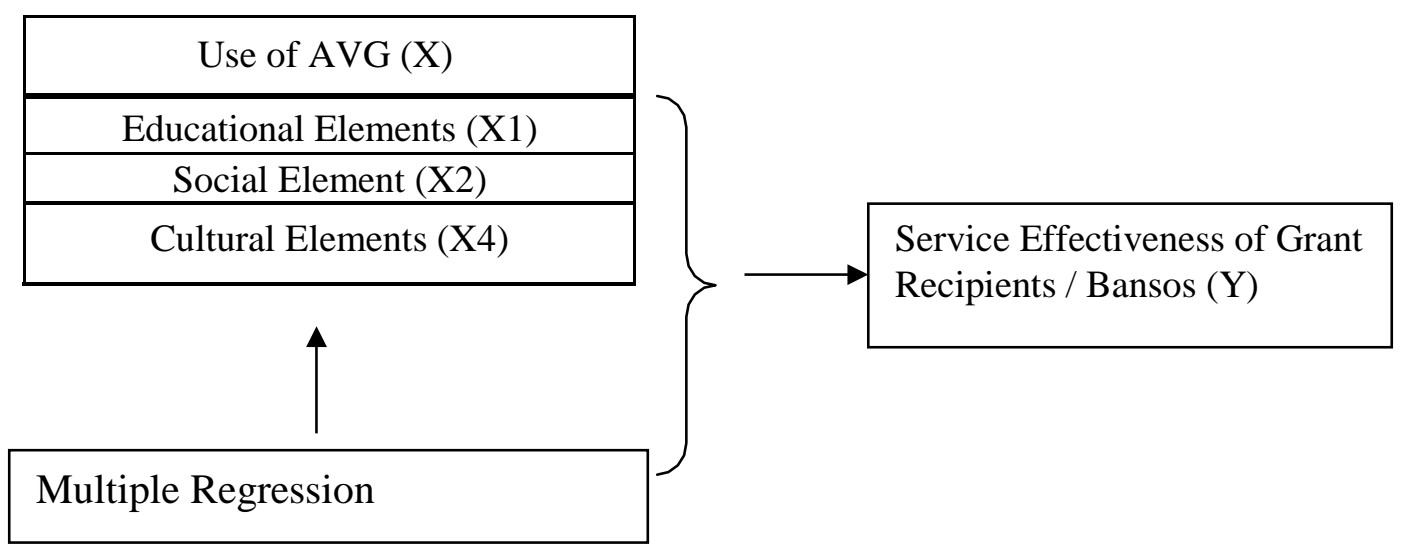

Figure 1. Research Framework

\section{Data Collection Techniques}

For data collection needed in research, data collection techniques used in this study are:

a. Questionnaire

Is a data collection technique carried out by giving a set of questions or written statements to respondents to answer (Sugiyono, 2011).

b. Interview (interview)

This technique is used to collect data, namely by making direct observations on the activities contained in the research object and conducting interviews with parties related to the problem to be studied.

c. Documentation

The documentation collected is in the form of data relating to the implementation of Perwali No. $15 / 2016$.

\section{Sampling Technique}

Population is a generalization area consisting of objects or subjects that have certain qualities and characteristics set by the researcher for study and then draw conclusions (Sugiyono, 2013). The population in this study were community groups (PokMas) who received social assistance in the city of Bogor.

The population of this research is the people who receive grants / social assistance in the 2017 budget year. The determination of the number of respondents is determined using the Slovin formula.

$$
\mathrm{n}=\frac{\mathrm{N}}{1+\mathrm{Ne}^{2}}
$$


Where: $\mathrm{n}=$ sample size to be searched

$\mathrm{N}=$ population size

$\mathrm{e}=$ margin of error which is the amount of error expected

In this study, the respondents used were 98 respondents

\section{Data Analysis Techniques}

The data processing methods used in this study consist of two types, including:

1. Validity Test

The validity test is used to determine the feasibility of items in a list (construct) of questions in defining a variable. The list of questions on the questionnaire generally supports a certain group of variables.

2. Reliability Test

Reliability (reliability) is a measure of stability and consistency of respondents in answering matters relating to question constructs which are the dimensions of a variable and arranged in a questionnaire form.

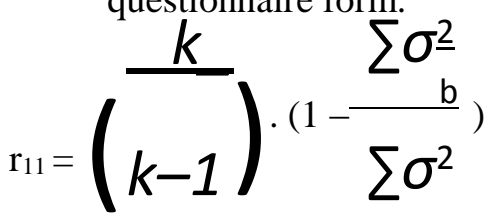

Information:

$\mathrm{r}_{11} \quad:$ instrument reliability

$\underline{k} \quad:$ the number of questions

$\sum \sigma_{b}^{2}:$ the number of various grains

$\sum \sigma_{t}^{2}:$ total variety (Priyanto, 2008)

1. Descriptive Analysis

The purpose of this descriptive analysis refers to the purpose of descriptive research, which is to make descriptions, pictures or paintings systematically, factually and accurately regarding the facts, characteristics and relationships between the phenomena being investigated. (Sugiyono, 2013) states descriptive statistics are statistics used to analyze data by describing or describing the collected data as it is without intending to make general conclusions or generalizations.

2. Test the Regression Coefficient

Regression analysis is an analysis used to determine the dependence of one variable ( $\mathrm{Y}$ ) (dependent variable) on one or more other variables (X) (independent variable). (Gujarati, 2010: 12). In this study the relationship between the Educational Elements (X1), Social (X2), Economical (X3) and Cultural (X4) variables (as independent variables) on the Effectiveness variable in the Grants / Social Assistance Service (Y) (as the dependent variable) is the equation multiple regression as follows; (Gujarati, 2010: 91).

$\mathrm{Y}=\beta 0+\beta 1 \mathrm{X} 1+\beta 2 \mathrm{X} 2+\beta 3 \mathrm{X3}+\beta 4 \mathrm{X} 4+$ ei

Keterangan :

$\beta 0=$ Constant number

$\beta 1,2,3,4=$ Regression coefficient

ei $=$ Confounding factor / error

$\mathrm{X} 1=$ Educative Elements 
$\mathrm{X} 2=$ Social Element

$\mathrm{X} 3$ = Economical Elements

$\mathrm{X} 4=$ Cultural Elements

$\mathrm{Y}=$ Dependent variable (Effectiveness in Grant Recipient Services / Bansos)

3. Classic Assumption Violation Test

In the rule of econometric statistics, when using multiple linear regression, it is necessary to first test possible violations of classical assumptions, namely the normality test, multicollinearity test, and heteroscedasticity test.

a. Normality test

The formulated hypothesis will be tested with parametric statistics, in this case by using correlation and regression.

b. Multicollinearity Test

The multicollinearity test is to see whether or not there is a high correlation between the independent variables in a multiple linear regression model.

c. Heteroscedasticity Test

According toGhozali (2011) the heteroscedasticity test aims to test whether in the regression model there is an inequality of variance from the residues of one observation to another.

d. Autocorrelation Test

According to Ghozali (2011) the autocorrelation test aims to test whether in the linear regression model there is a correlation between the confounding error in period $t$ with the confounding error in period t-1 (previous).

\section{RESEARCH RESULTS AND DISCUSSION}

\section{Research Results}

\section{Characteristics of Respondents}

In this study, some characteristics regarding respondents who are eligible for grants / social assistance in the Bogor City area include Gender, Age, Education, Total Income, District Origin and Type of Assistance. These characters are not only based on assumptions by researchers, but there are also some references that researchers read or interview with resource persons. Respondents were taken randomly (randomly) as many as the number of samples that had been obtained from calculations with Slovin Theory, namely as many as 98 samples. The questionnaire was distributed to the community who received the Grant/ Bansos based on data from the Community Welfare Office and from the village concerned in Bogor City.

The following is a descriptive description of the respondent's character as follows:

a. Respondents Based on Gender

Table 1. Respondents by Gender

\begin{tabular}{lcl}
\hline Gender & Frequency & Percentage \\
\hline Men & 49 & $50 \%$ \\
Woman & 49 & $50 \%$ \\
& $\mathbf{9 8}$ & $\mathbf{1 0 0 \%}$ \\
\hline Amount & Source: research results, 2018
\end{tabular}

b. Number of Respondents by Age

Table 2. Respondents by Age 


\begin{tabular}{lll}
\hline Age & Frequency & Percentage \\
\hline$>50$ & 28 & $29 \%$ \\
$36-50$ & 49 & $50 \%$ \\
$21-35$ & 21 & $21 \%$ \\
$=<20$ & $\underline{0}$ & $\underline{0 \%}$ \\
\cline { 1 - 1 } Amount & $\mathbf{9 8}$ & $\mathbf{1 0 0 \%}$ \\
\hline
\end{tabular}

Source: research results, 2018

c. Respondents Based on Education

Table3. Respondents Based on Education

\begin{tabular}{lll}
\hline Education & Frequency & Percentage \\
\hline College & 0 & $0 \%$ \\
High school & 3 & $3 \%$ \\
Junior High School & 7 & $7 \%$ \\
Primary school & 88 & $90 \%$ \\
\hline Amount & 98 & $100 \%$ \\
\hline
\end{tabular}

Source: research results, 2018

d. Respondents Based on Income

Table 4. Respondents Based on Income

\begin{tabular}{lll}
\hline Income & Frequency & Percentage \\
\hline$>1,5$ Juta & 0 & $0 \%$ \\
$=<1,5$ Juta & 0 & $0 \%$ \\
$=<1$ Juta & 0 & $0 \%$ \\
$=<500$ ribu & 98 & $100 \%$ \\
\hline Amount & 98 & $100 \%$ \\
\hline
\end{tabular}

Source: research results, 2018

4 Analysis of Respondents Based on the Questionnaire Regarding the Use of Audio Visual Graphic Media and the Effectiveness of Grant Recipients / Bansos

Table 5. Results of the questionnaire regarding the educational elements

\begin{tabular}{|l|l|l|l|l|l|l|l|}
\hline No & Elements Edukative $\left(\mathbf{X}_{1}\right)$ & SE & E & KE & TE & STE & TOTAL \\
\hline 1 & $\begin{array}{l}\text { Is it effective with the use of Audio } \\
\text { Visual Graphics can provide } \\
\text { educational value for Grant recipients / } \\
\text { Bansos }\end{array}$ & 5 & 16 & 25 & 48 & 4 & 98 \\
\hline 2 & $\begin{array}{l}\text { Is it effective with the use of Audio } \\
\text { Visual Graphics to educate the public to } \\
\text { think critically for the Grantees / } \\
\text { Bansos recipients }\end{array}$ & 5 & 16 & 20 & 53 & 4 & 98 \\
\hline
\end{tabular}




\begin{tabular}{|l|l|l|l|l|l|l|l|}
\hline 3 & $\begin{array}{l}\text { Is it effective with the use of Audio } \\
\text { Visual Graphics can provide } \\
\text { meaningful experiences for Grant } \\
\text { recipients / Bansos }\end{array}$ & 5 & 15 & 34 & 40 & 4 & 98 \\
\hline $\begin{array}{l}\text { Is it effective with the use of Audio } \\
\text { Visual Graphics can develop and } \\
\text { expand the horizons of thinking for } \\
\text { Grant recipients / Bansos }\end{array}$ & 4 & 19 & 32 & 39 & 4 & 98 \\
\hline Frequency & 19 & 66 & 111 & 180 & 16 & 392 \\
\hline Percentage & $5 \%$ & $17 \%$ & $28 \%$ & $46 \%$ & $4 \%$ & $1696 \%$ \\
\hline Weight & 5 & 4 & 3 & 2 & 1 & 1068 \\
\hline Fx) & 95 & 264 & 333 & 360 & 16 & $\mathbf{2 , 7 2}$ \\
\hline Average Score of the Questionnaire & 2,724489796 & & & \\
\hline Information & Less effective & & & \\
\hline
\end{tabular}

Source: research results, 2018

Based on Table 5 regarding the respondent's analysis data on Educational Elements, it is known that people who are eligible to apply for Grants / Bansos state 5\% Very Effective and 17\% say Effective, $28 \%$ say Not Effective and $46 \%$ Ineffective and Very Ineffective by $4 \%$.

Table 6. Results of Respondents' Answers to Questions related to the Educational Element

\begin{tabular}{|l|l|l|l|l|l|l|}
\hline Educative Elements & \multicolumn{3}{|l|}{ Question } & \multirow{2}{*}{ Average } & \multirow{2}{*}{$\%$} \\
\cline { 1 - 6 } & \multicolumn{1}{|l|}{1} & 2 & 3 & 4 & & \\
\hline Weight Value / Description & 5 & 5 & 5 & 4 & 4,75 & $5 \%$ \\
\hline Value 5 (Very Effective) & 16 & 16 & 15 & 19 & 16,5 & $17 \%$ \\
\hline Value 3 (Effective) & 25 & 20 & 34 & 32 & 27,75 & $28 \%$ \\
\hline Score 2 (Ineffective) & 48 & 53 & 40 & 39 & 45 & $46 \%$ \\
\hline Value 1 (Very Ineffective) & 4 & 4 & 4 & 4 & 4 & $4 \%$ \\
\hline Amount & 98 & 98 & 98 & 98 & 98 & $100 \%$ \\
\hline
\end{tabular}

Source: research results, 2018

Table 7. Questionnaire results on Social Elements

\begin{tabular}{|l|l|l|l|l|l|l|l|}
\hline No & Unsur Sosial $\left(\mathbf{X}_{2}\right)$ & SE & E & KE & TE & STE & TOTAL \\
\hline 1 & $\begin{array}{l}\text { Is it effective with the use of Audio } \\
\text { Visual Graphics can provide } \\
\text { information so as to broaden the } \\
\text { association for Grant recipients / } \\
\text { Bansos }\end{array}$ & 2 & 23 & 63 & 6 & 4 & 98 \\
\hline 2 & $\begin{array}{l}\text { Is it effective with the use of Audio } \\
\text { Visual Graphics to get to know each } \\
\text { other for Grant recipients / Bansos }\end{array}$ & 2 & 23 & 62 & 7 & 4 & 98 \\
\hline 3 & $\begin{array}{l}\text { Is it effective with the use of Audio } \\
\text { Visual Graphics to understand each } \\
\text { other for Grant recipients / Bansos }\end{array}$ & 3 & 19 & 62 & 9 & 5 & 98 \\
\hline
\end{tabular}




\begin{tabular}{|l|l|l|l|l|l|l|l|}
4 & $\begin{array}{l}\text { Is it effective with the use of Audio } \\
\text { Visual Graphics can provide lessons } \\
\text { about customs and interactions } \\
\text { between Grant recipients / Bansos }\end{array}$ & 4 & 17 & 66 & 7 & 4 & 98 \\
\hline Frequency & 11 & 82 & 253 & 29 & 17 & 392 \\
\hline Percentage & $3 \%$ & $21 \%$ & $65 \%$ & $7 \%$ & $4 \%$ & $100 \%$ \\
\hline Weight & 5 & 4 & 3 & 2 & 1 & 1217 \\
\hline (Fx) & 55 & 328 & 759 & 58 & 17 & $\mathbf{3 , 1 0}$ \\
\hline Average Score of the Questionnaire & 3,104591837 & & & & \\
\hline Information & \multicolumn{2}{l|l}{ Less effective } & & & & \\
\hline
\end{tabular}

Source: research results, 2018

Based on Table 7 regarding the respondent's analysis data on the Social Elements, it is known that people who are eligible to apply for Grants / Bansos state 3\% Very Effective and 21\% say Effective, 65\% say Ineffective and 7\% Ineffective and Very Ineffective by $4 \%$.

Table 8. Results of Respondents' Answers to Questions related to Social Elements

\begin{tabular}{|l|l|l|l|l|l|l|}
\hline Social Elements & \multicolumn{4}{|l|}{ Question } & \multirow{2}{*}{ Average } & \multirow{2}{*}{$\%$} \\
\hline Weight Value / Description & 1 & 2 & 3 & 4 & & \\
\hline Value 5 (Very Effective) & 2 & 2 & 3 & 4 & 2,75 & $3 \%$ \\
\hline Value 4 (Effective) & 23 & 23 & 19 & 17 & 20,5 & $21 \%$ \\
\hline Value 3 (Less Effective) & 63 & 62 & 62 & 66 & 63,25 & $65 \%$ \\
\hline Score 2 (Ineffective) & 6 & 7 & 9 & 7 & 7,25 & $7 \%$ \\
\hline Value 1 (Very Ineffective) & 4 & 4 & 5 & 4 & 3 & $3 \%$ \\
\hline Amount & 98 & 98 & 98 & 98 & 96,75 & $100 \%$ \\
\hline
\end{tabular}

Source: research results, 2018

Table 9. Questionnaire results on Economic Elements

\begin{tabular}{|l|l|l|l|l|l|l|l|}
\hline No & with Economic Elements (X3) & SE & E & KE & TE & STE & TOTAL \\
\hline 1 & $\begin{array}{l}\text { Is it effective with the use of } \\
\text { Audio Visual Graphics can } \\
\text { reduce the use of costs for Grant } \\
\text { recipients / Bansos }\end{array}$ & 6 & 31 & 52 & 5 & 4 & 98 \\
\hline 2 & $\begin{array}{l}\text { Is it effective with the use of } \\
\text { Audio Visual Graphics can } \\
\text { reduce the use of energy for } \\
\text { Grant recipients / Bansos }\end{array}$ & 8 & 26 & 53 & 7 & 4 & 98 \\
\hline 3 & $\begin{array}{l}\text { Is it effective with the use of } \\
\text { Audio Visual Graphics can } \\
\text { reduce the use of time for Grant } \\
\text { recipients / Bansos }\end{array}$ & 8 & 24 & 52 & 10 & 4 & 98 \\
\hline 4 & $\begin{array}{l}\text { Is it effective with the use of } \\
\text { Audio Visual Graphics so that } \\
\text { the purpose of the information is } \\
\text { achieved for the Grantees / } \\
\text { Bansos recipients }\end{array}$ & 6 & 16 & 58 & 12 & 6 & 98 \\
\hline
\end{tabular}




\begin{tabular}{|l|l|l|l|l|l|l|}
\hline Frequency & 28 & 97 & 215 & 34 & 18 & 392 \\
\hline Percentage & $7 \%$ & $25 \%$ & $55 \%$ & $9 \%$ & $5 \%$ & $100 \%$ \\
\hline Weight & 5 & 4 & 3 & 2 & 1 & \\
\hline (Fx) & 140 & 388 & 645 & 68 & 18 & 1259 \\
\hline Average Score of the Questionnaire & 3,211734694 & & & $\mathbf{3 , 2 1}$ \\
\hline Information & Less effective & \\
\hline
\end{tabular}

Source: research results, 2018

Based on Table 9 regarding the respondent's analysis data on Economic Elements, it is known that people who are eligible to apply for Grants / Social Assistance states 7\% Very Effective and 25\% stated Effective, 55\% stated Ineffective and 9\% Ineffective and Very Ineffective by 5\%.

Table 10. Results of Respondents' Answers to Questions related to the Economic Element

\begin{tabular}{|l|l|l|l|l|l|l|}
\hline Economy Elements & \multicolumn{3}{|l|}{ Question } & \multirow{2}{*}{ Average } & $\%$ \\
\cline { 1 - 6 } Weight Value / Description & 1 & 2 & 3 & 4 & & \\
\hline Value 5 (Very Effective) & 6 & 8 & 8 & 6 & 7 & $7 \%$ \\
\hline Value 4 (Effective) & 31 & 26 & 24 & 16 & 24,25 & $25 \%$ \\
\hline Value 3 (Less Effective) & 52 & 53 & 52 & 58 & 53,75 & $55 \%$ \\
\hline Score 2 (Ineffective) & 5 & 7 & 10 & 12 & 8,5 & $9 \%$ \\
\hline Value 1 (Very Ineffective) & 4 & 4 & 4 & 6 & 4,5 & $5 \%$ \\
\hline Amount & 98 & 98 & 98 & 98 & 98 & $100 \%$ \\
\hline
\end{tabular}

Source: research results, 2018

Table 11. The results of the questionnaire on Cultural Elements

\begin{tabular}{|l|l|l|l|l|l|l|l|}
\hline No & Cultural Elements (X4) & SE & E & KE & TE & STE & TOTAL \\
\hline 1 & $\begin{array}{l}\text { Is it effective with the use of Audio } \\
\text { Visual Graphics can give a } \\
\text { positive impact on a daily basis for } \\
\text { the Grantees / Bansos recipients }\end{array}$ & 1 & 23 & 67 & 3 & 4 & 98 \\
\hline $\begin{array}{l}\text { Is it effective with the use of Audio } \\
\text { Visual Graphics to convey the next } \\
\text { information for Grant recipients / } \\
\text { Bansos }\end{array}$ & 3 & 20 & 66 & 5 & 4 & 98 \\
\hline $\begin{array}{l}\text { Is it effective with the use of Audio } \\
\text { Visual Graphics can convey art for } \\
\text { Grant recipients / Bansos }\end{array}$ & 2 & 18 & 67 & 7 & 4 & 98 \\
\hline $\begin{array}{l}\text { Is it effective with the use of Audio } \\
\text { Visual Graphics to change the } \\
\text { culture in the community, } \\
\text { especially for Grant recipients / } \\
\text { Bansos }\end{array}$ & 5 & 20 & 61 & 8 & 4 & 98 \\
\hline Frequency & 11 & 81 & 261 & 23 & 16 & 392 \\
\hline Percentage & $3 \%$ & $21 \%$ & $67 \%$ & $6 \%$ & $4 \%$ & $100 \%$ \\
\hline Weight & 5 & 4 & 3 & 2 & 1 & \\
\hline (Fx) & 55 & 324 & 783 & 46 & 16 & 1224 \\
\hline Average Score of the Questionnaire & 3,12244898 & & & $\mathbf{3 , 1 2}$ \\
\hline Information & Less effective & & & \\
\hline
\end{tabular}


Source: research results, 2018

Based on Table11 regarding the respondent's analysis data on Cultural Elements, it is known that people who are eligible to apply for Grants / Bansos state 3\% Very Effective and 21\% say Effective, $67 \%$ say Ineffective and 6\% Ineffective and 4\% Very Ineffective

Table 12. Results of Respondents' Answers to Questions related to the Economic Element

\begin{tabular}{|l|l|l|l|l|l|l|}
\hline Economic Elements & \multicolumn{3}{|l|}{ Question } & \multirow{2}{*}{ Average } & \multirow{2}{*}{$\%$} \\
\cline { 1 - 5 } Weight Value / Description & 1 & 2 & 3 & 4 & & \\
\hline Value 5 (Very Effective) & 1 & 3 & 2 & 5 & 2,75 & $3 \%$ \\
\hline Value 4 (Effective) & 23 & 20 & 18 & 20 & 20,25 & $21 \%$ \\
\hline Value 3 (Less Effective) & 67 & 66 & 67 & 61 & 65,25 & $67 \%$ \\
\hline Score 2 (Ineffective) & 3 & 5 & 7 & 8 & 5,75 & $6 \%$ \\
\hline Value 1 (Very Ineffective) & 4 & 4 & 4 & 4 & 4 & $4 \%$ \\
\hline Amount & 98 & 98 & 98 & 98 & 98 & $100 \%$ \\
\hline
\end{tabular}

Source: research results, 2018

Data Analysis

1. Test Instruments

a. Validity test

Table 13. Validity Test Results on Question Points Related to Educational Elements, Social Elements, Economic Elements and Cultural Elements

\begin{tabular}{llllll}
\hline No & Variable & $\begin{array}{l}\text { Range } \\
\text { Corelation }\end{array}$ & R Table & Significance & Information \\
\hline 1 & Educative Elements &, $903-, 941$ & 0,2 & 0,05 & Valid \\
2 & Social Element &, $877-, 926$ & 0,2 & 0,05 & Valid \\
3 & Economic Elements &, $676-, 898$ & 0,2 & 0,05 & Valid \\
4 & Cultural Elements &, $904-, 937$ & 0,2 & 0,05 & Valid \\
\hline
\end{tabular}

Sumber: hasil penelitian, 2018.

Based on Table 13, data processing assisted with the SPSS 20 application shows that all questions are valid, because rcount is greater than rtable (for $\mathrm{n}=98, \mathrm{df}=96$ with $\alpha=0.05$, namely 0.2 ). So it can be said that the question items on variables related to the Educational Element, the Social Element, the Economic Element and the Cultural Element are said to be valid.

b. Reliability Test

Table 14. Reliability Test on Question Points Related to Educational Elements, Social Elements, Economic Elements and Cultural Elements

\begin{tabular}{|c|c|c|c|c|}
\hline No & Variable & $\begin{array}{l}\text { Value } \\
\text { Alpha }\end{array}$ & Croncbach's & Information \\
\hline 1 & Educative Elements & ,967 & & Reliabel \\
\hline 2 & Social Element & ,960 & & Reliabel \\
\hline 3 & Economic Elements & ,926 & & \\
\hline 4 & Cultural Elements & 964 & & Reliabel \\
\hline
\end{tabular}


Source: research results, 2018

Based on the reliability test shown in table 14, it can be seen that the value of Cronbach's Alpha in the Educative Elements, Social Elements, Economic Elements and Cultural Elements variables whose value is greater than 0.60. So it can be concluded that the question construct which is the dimension of all variables is reliable

c. Multiple Linear Regression Test

In this study, the relationship between the variables of Educational Elements, Social Elements and Economic Elements (as independent variables) to the variables worthy of receiving grants / social assistance (as the dependent variable).

d. Multiple Linear Regression Coefficient

Coefficients $^{\mathrm{a}}$

Table 15. Multiple Linear Regression

\begin{tabular}{|c|c|c|c|c|c|c|}
\hline \multirow{2}{*}{ Model } & & \multicolumn{2}{|c|}{ Unstandardized Coefficients } & $\begin{array}{l}\text { Standardized } \\
\text { Coefficients }\end{array}$ & \multirow{2}{*}{$\mathrm{T}$} & \multirow{2}{*}{ Sig. } \\
\hline & & & & & & \\
\hline \multirow{5}{*}{1} & (Constant) & .793 & 205 & & 3.868 & .000 \\
\hline & Educative &,- 026 & 074 &,- 038 &,- 355 &, 723 \\
\hline & Social & ,255 & 135 & ,276 & 1,888 & 062 \\
\hline & Economy & 321 & 116 & ,399 & 2,756 & ,007 \\
\hline & Culture &, 154 &, 124 & ,168 & 1,240 & 218 \\
\hline
\end{tabular}

a. Dependent Variable: Effectiveness

Source: research results, 2018

The form of the regression equation can be written as follows:

$$
Y=0,793-0,026 X_{1}+0,255 X_{2}+0,321 X_{3}+0,154 X_{4}
$$

Where :

$\mathrm{X} 1=$ Educative Elements

$\mathrm{X} 2=$ Social Element

$\mathrm{X} 3$ = Economic Elements

$\mathrm{X} 4=$ Elements of Culture

$\mathrm{Y}=$ Effectiveness of Grant Recipients / Bansos

The results of the multiple linear regression equation in table 4:15 provide the understanding that:

1) For the Educational Element variable (X1) the regression coefficient is negative, this means that if the educational element is getting better, the effectiveness of the grantee / social assistance will decrease. If the Educational Element variable (X1) increases by 1 unit, then the effectiveness of the community applying for Grants / Social Assistance decreases by - 0.026 Ceteris Paribus units.

2) For the Social Element variable (X2) the regression coefficient is also positive, this can be interpreted that if the Social Element is getting better, the effectiveness of the community who receives the grant / social assistance will increase. that is, if the Social Element variable increases by 1 unit, the effectiveness of the community applying for grants / social assistance will increase by +0.255 Ceteris Paribus units.

3) For the Economic Element variable (X3) the regression coefficient is also positive, this can be interpreted that if the Economic Element is getting better, the effectiveness of the community who receives the grant / social assistance will increase. that is, if the Economic Element variable increases by 1 unit, then the effectiveness of the community applying for grants / social assistance will increase by +0.321 units of Ceteris Paribus.

4) For the Cultural Element variable (X4) the regression coefficient is also positive, this can be interpreted that if the Cultural Element is getting better, the effectiveness of the community who receives the grant / social assistance will increase. that is, if the Cultural Elements variable increases by 1 unit, then the effectiveness of the community applying for grants / social assistance will increase by +0.321 Ceteris Paribus units. 
Based on the results of the analysis above, it can be said that the Economic Elements variable has the greatest influence on the effectiveness of the people who apply for grants / social assistance in the Bogor City Government, which is 0.321 compared to the Social, Cultural and Educational Elements variables.

Coefficient of Determination $\left(\mathrm{R}^{2}\right)$

Table 16. Coefficient of Determination

Model Summary

\begin{tabular}{llllll}
\hline Model & $\mathrm{R}$ & R Square & Adjusted R Square & $\begin{array}{l}\text { Std. Error of the } \\
\text { Estimate }\end{array}$ & Durbin-Watson \\
\hline 1 &, $771^{\mathrm{a}}$ &, 595 &, 578 &, 41067 & 2,073 \\
\hline
\end{tabular}

a. Predictors: (Constant), Cultural, Educational, Economic, Social

b. Dependent Variable: Effectiveness

Source: research results, 2018

c. Simultaneous Signification Test (Test F)

Table17. Test $F$

ANOVA $^{\mathrm{a}}$

\begin{tabular}{lllllll}
\hline Model & & Sum of Squares & df & Mean Square & F & Sig. \\
\hline & Regression & 23,057 & 4 & 5,764 & 34,180 &, $000^{\mathrm{b}}$ \\
1 & Residual & 15,684 & 93 &, 169 & & \\
& Total & 38,741 & 97 & & &
\end{tabular}

a. Dependent Variable: Effectiveness

b. Predictors: (Constant), Cultural, Educational, Economic, Social

Source: research results, 2018

Table 18. Individual Parameter Significance Test ( $t$ test)

Coefficientsa

\begin{tabular}{lllllll}
\hline Model & & \multicolumn{2}{l}{ Unstandardized Coefficients } & $\begin{array}{l}\text { Standardized } \\
\text { Coefficients } \\
\text { Beta }\end{array}$ & T & Sig. \\
& & B & Std. Error & Beta & \\
\hline & (Constant) &, 793 &, 205 & & 3,868 &, 000 \\
1 & Educative &,- 026 &, 074 &,- 038 &,- 355 &, 723 \\
& Social &, 255 &, 135 &, 276 & 1,888 &, 062 \\
& Economy &, 321 &, 116 &, 399 & 2,756 &, 007 \\
& Culture &, 154 &, 124 &, 168 & 1,240 &, 218 \\
\hline
\end{tabular}

a. Dependent Variable: Effectiveness

2. Classic Assumption Violation Test 
a. Normality test

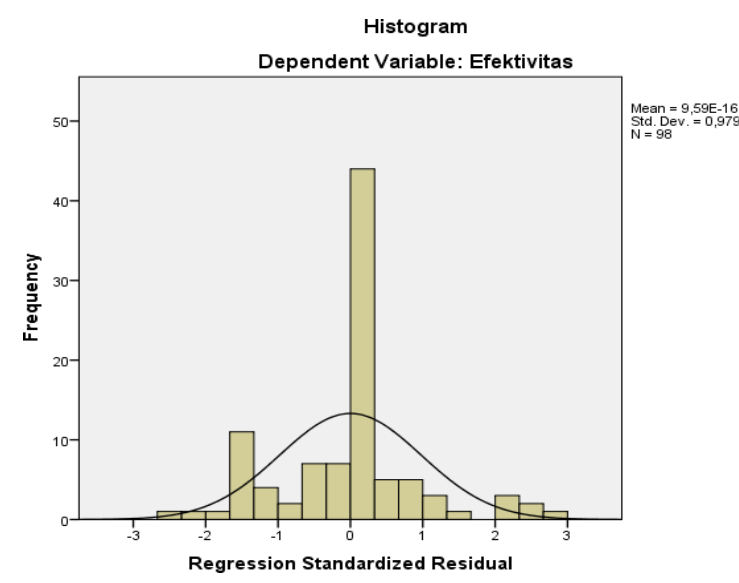

Figure 4.1 Histsogram

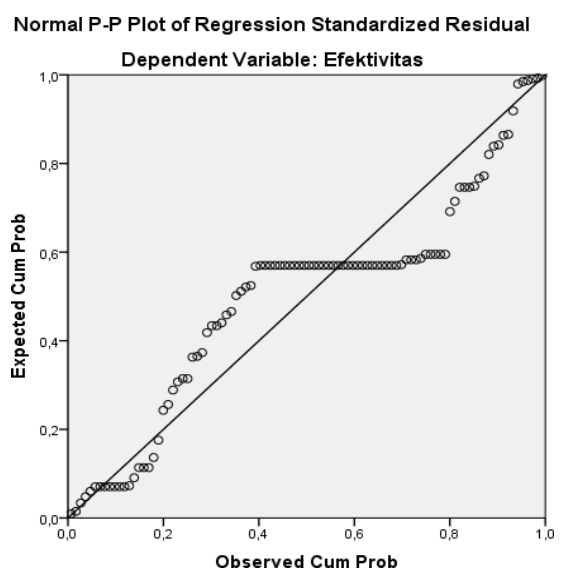

Figure 4.2 Normal P.P

\section{Discussion}

The function of audio visual media in learning in the context of communication has a very broad function, namely as follows:

1. Educative function, providing educational value influence, educating students and society to think critically, providing meaningful experiences, and developing and broadening students' thinking horizons.

2. Social function, providing authentic information in various fields of life and the same concept to everyone so as to expand relationships, recognition, understanding of people, customs and ways of getting along.

3. Economic function, by using educational media the achievement of goals can be carried out efficiently, delivery of material can reduce the use of costs, energy and time as little as possible without reducing effectiveness in achieving goals.

4. Cultural functions, providing changes in the aspects of human life, can pass on and carry on cultural and artistic elements that exist in society

Based on the results of the answers to the questionnaires distributed to respondents, it is known that:

Table 19 Average Score of Audio Visual Graphic Media Usage Variable

\begin{tabular}{|l|l|l|l|}
\hline No & Indicator & Average Score & Description \\
\hline 1 & Elements Edukative & 2,72 & Less effective \\
\hline 2 & Elements Social & 3,10 & Less effective \\
\hline 3 & Elements Economy & 3,21 & Less effective \\
\hline 4 & ElementsCulture & 3,12 & Less effective \\
\hline
\end{tabular}

Source: research results, 2018

From the ANOVA test or F-Test, it is found that the value of Fcount is 34.180 with a significance level of 0.000 . Because the probability is smaller than 0.05 , the regression model can be used to predict Y.So it can be concluded that simultaneously the Educational Elements (X1), Social Elements (X2), Economic Elements (X3) and Cultural Elements (X4) affect the Effectiveness variable. Grant Recipient/ Bansos (Y).

While the results spatially show that the variables of Educational Elements (X1), Social Elements (X2) and Cultural Elements (X4) partially have no effect on the Variable Effectiveness of 
Grant Recipients / Social Assistance (Y) in the Community of Bogor City. This is because t count $<\mathrm{t}$ table $(\alpha=5 \%$ obtained $\mathrm{t}$ table 1.987). So that all the variables used in this study accept $\mathrm{H} 0$ and reject Ha. Meanwhile, the Economic Element rejects Ho and accepts Ho. For the t-calculated probability value of the independent variable (X), namely the Educational Element, the Social Element, the Economic Element and the Cultural Element towards the Grants / Social Assistance Beneficiary Effectiveness variable $(\mathrm{Y})$ of 0.000 which is smaller than 0.05 so that it has a significant effect on the dependent variable. People who submit a proposal for Grant Assistance / Social Assistance at 5\% alpha, in other words the Educational Element, the Social Element, the Economic Element and the Cultural Element have a significant effect on the effectiveness of the people of the city of Bogor who submit a grant/ Bansos assistance proposal at the $95 \%$ confidence level.

\section{CONCLUSION}

Based on the results of the study, it can be concluded that:

a. Educational elements have no effect on the effectiveness of grant recipients / social assistance in Bogor City;

b. Social elements do not affect the effectiveness of grantees / social assistance recipients in Bogor City;

c. Economic elements affect the effectiveness of grant recipients / social assistance in Bogor City;

d. Cultural elements do not affect the effectiveness of grantees / social assistance recipients in the city of Bogor;

e. The economic element that has the greatest influence on the effectiveness of people who apply for grants / social assistance in the Bogor City Government is 0.321 .

\section{Suggestion}

Based on the results of research simultaneously and partially that the educational elements, social elements, economic elements and cultural elements are less effective and 3 variables, namely the educational elements, social elements, and cultural elements have no effect, then:

a. It is hoped that the Bogor City government, especially the Community Welfare Section in the Bogor Regional Government, will conduct more socialization with the use of Audio Visual Graphic Media to the community who receive grants / social assistance.

b. Based on the research results, the educational element in being the lowest. Some questions regarding:

1) Effective in providing educational value

2) Effective in educating people to think critically,

3) Effective in providing meaningful experiences

4) Effective in developing and broadening the horizons of thinking

In the 4 questions related to educational elements, critical thinking has the smallest value, followed by developing and broadening the horizons of thinking in each community that submits a proposal or is related to the process of submitting grant assistance / social assistance. So in this case, it is advisable to further improve appropriate socialization and education to the community, especially grant recipients / social assistance, especially in the use of Information Technology.

\section{REFERENCES}

Arindawati. 2004. Model Pembelajaran Student Team Achievement Division.Http://www.Scrbd.com.

Arsyad, Azhar.2002. Media Pembelajaran, edisi 1. Jakarta: PT. Raja Grafindo. Persada

Ainina, Indah Ayu , 2014, Pemanfaatan Media Audio Visual Sebagai Sumber Pembelajaran Sejarah. Fakultas Ilmu Sosial, Universitas Negeri Semarang Kampus Sekaran, Gunungpati, Kota Semarang 50229. Vol 3 No 1 
Gujarati, Damodar. 2010. Dasar-Dasar Ekonometrika (Buku 1, edisi ke-5). Jakarta: Salemba Empat

Ghozali, Imam. 2011. Aplikasi Analisis Multivariate Dengan Program SPSS.Semarang, Universitas Diponegoro.

Hadari Nawawi, 2006. Kepemimpinan Yang Efektif. Yogyakarta: UGM Press.

Harahap, Riezky Hadhisti, 2018, Implementasi Dana Hibah dan Bansos Berdasarkan Permendagri Nomor 39 Tahun 2012, Tentang Pedoman Pemberian Hibah dan Bantuan Sosial Yang Bersumber dari APBD Terhadap Transparansi Penyerapan Anggaran Hibah dan Bantuan Sosial di Kota Pontianak, https://jurnal.untan.ac.id/index.php/maksi/article/view/28235

Lapananda, Yusran, 2013 Penerbit, : Sinar Grafika, Jakarta

Lupiyoadi, Rambat dan A. Hamdani. 2011. Manajemen Pemasaran Jasa Edisi 2. Jakarta: Salemba Empat.

Nawawi, H. Hadari. 2011.Manajemen Sumber Daya Manusia untuk bisnis yang kompetitif. Yogyakarta: Gadjah Mada University Pres

Sanusi, Anwar. 2011, Metode Penelitian Bisnis, Jakarta, Salemba Empat.

Soewarno, Handayaningrat, 2002. Pengantar Studi Ilmu Administrasi dan Manajemen. Jakarta: CV Haji Masagung.

Sianturi, Holmes, 2017, Kedudukan Keuangan Daerah dalam Pengelolaan Dana Hibah dan Bantuan Sosial Berdasarkan Perspektif Keuangan Negara, Vol 1, No , Jurnal Wawasan Yuridika

Sugiyono. 2011. Metode Penelitian Pendidikan. Cetakan ke 10.Bandung, Alfa Beta.

Sugiyono. 2012. Statistika untuk Penelitian. Bandung: Alfa Beta.

Susanto, Heri. 2017. Pengaruh Kedisiplinan Karyawan dalam Implementasi Hibah/Bansos No. 15 tahun 2016 terhadap Kepuasan Penerima Hibah/Bansos di Kota Bogor”. Jurnal Unpak. http://jurnal.unpak.ac.id/index.php/jimfe 